\title{
Visual Landscape Quality Assessment in Historical Cultural Landscape Areas
}

\author{
Emine Keleş ${ }^{1}$, Damla Atik², Gökçen Bayrak ${ }^{2}$
}

\begin{abstract}
Various factors such as rapid population increase, socio-economic changes and uncontrolled urbanization observed in cities caused many changes in urban areas. These changes damage natural and cultural landscape areas. It is observed that especially historical landscape areas couldn't be protected as well as planning and management of these areas couldn't be provided. Accordingly, constitution of inventory studies oriented natural, cultural and historical sources; presentation of planning and management decisions and arrangements that are integrated to historical identity and increasing environmental quality are steered. Visual Landscape Quality Assessment is one of the methods used in both our country and in the world for planning studies within the context of European Landscape Convention. The visual character of landscape consists of both natural-human made artifacts and physical-biological sources. The assessment includes a list of areas that are subject to cultural heritage conservation; it lends assistance for identifying various factors and preferences of physical landscape components. Edirne/Turkey is one of the most significant cities of the world being a cultural heritage area with its tangible and intangible cultural landscape elements. It is aimed to contribute to rational planning and conserving of cultural resources by preparing visual landscape quality assessment of Edirne city in this study.
\end{abstract}

Keyword: Visual landscape quality assessment, historic cultural landscape, cultural heritage, cultural sustainability, Edirne

\section{Introduction}

In our day, education, business and health oppurtunities and technological developments make urban life attractive. However, this situation has inevitable negative influences on human. The psychological pressure which is a result of these negative influences alienates human from natural life and makes human beings' admirations and expectations different (Ak, 2013). Due to the rapid changes in cities, settlements gradually lose their traditional values and identities by reshaping their physical and social structure (Hepcan, 2003). The visual problems, which are the reflection of changes in urban landscape, causes prestige loss of many settlements and decreases the values of natural-cultural landscape (Coşkun \& Kaplan, 2001). Researchs of visual impact assessment, which deals with the lost natural and cultural characteristics, physical development and social life of the settlements in the present context, gains importance (Hepcan, 2003).

While environmental issues are becoming more and more problematic and the size of green areas is decreasing day by day; the importance of natural resources are

| ${ }^{1}$ Lecturer, Trakya University, Faculty of Architecture, Department of Landscape Architecture, Makedonya Settlement, Edirne/Turkey

${ }^{2}$ Assistant Professor, Trakya University, Faculty of Architecture, Department of Landscape Architecture, Makedonya Settlement, Edirne/Turkey 
comprehended more seriously in today's conditions. Therefore, it can be accepted that the landscape is not just an economic issue but also an aesthetic one to evaluate and discuss about (Erdönmez \& Kaptanoğlu, 2008). "Visual quality assessment" becomes an indispensable research method when landscape is discussed as an aesthetic entity.

Perception is the process of selecting, organizing, and interpreting information received through senses (Porteus, 1996) (Bell, 1999). Theories about the perception of landscaping or physical environment are also important for environmental psychology. Theories and research on environment perception deal primarily with the processing of the mental images of individuals who seek to better understand and interpret what they surround their surrounding environment (Çakç1, 2007). The changing visual structure of the environment constantly affects user perception and the development of this visual quality gains importance in terms of meeting the aesthetic needs and expectations of people. For this, it is necessary to recognize the landscape as a variable in the land use decisions and to know the landscape properties and the visual value of these properties on the users (Kaptanoğlu, 2006) (Daniel T. , 2001).

Visual elements of landscape not only present aesthetical values but also verify the mutual relationships of these values in cultural, economic and biological dimensions (Daniel \& Vining, 1983) (Amir \& Gidalizon, 1990); (Angileri \& Toccolini, 1993). In this case, there is a need for planning studies that will strengthen the local texture of the cities and protect the identity by establishing a bridge between the past, contributing to the protection-improvement-renovation and continuity (Kiper, 2013).

According to the European Landscape Convention; every country needs to define, plan, protect and repair landscapes within its boundaries. In this context, the identification of the characteristics of natural and cultural landscapes also needs to be evaluated in our country and including historical landscapes in landscape planning studies is an important. It presents a solution proposal for revealing the human-environment interaction with the visual impact assessment studies, improving the living environment of the interaction results in terms of basic social and physical facilities and using it to bring the livable contemporary spaces to the square. In this way, solutions for physical planning and design studies and social life for the present and future of the settlements are provided (Bozhüyük, 2007). The aims of visual quality assessment are to help to determine and list the areas to be protected with the framework of cultural heritage protection program; to determine whether a landscape is aesthetically appropriate or not; to define and determine certain factors and physical landscape components that affect the preferences for this particular area (Kane, 1981).

Edirne which was the the capital of the Ottoman Empire and home to many civilizations, is the second gateway to the western border of Turkey as the nearest European settlement. The magnificent religious buildings and civil architectural items bearing the Ottoman architecture to its peak bring the identity of the city to the forefront. In this study, visual quality of historical and cultural landscape in Edirne city, city center and its vicinity is evaluated; it is aimed to contribute to the planning, designing, conservation, management and repair works of historical-cultural landscaping areas in the city center in line with the results obtained. 


\subsection{Historical Cultural Landscape}

During the 1990s, the interpretation of World Heritage evolved to a great extent, and as a result a diversity of living cultural places, sacred sites and cultural landscapes has been included on the United Nations Educational, Scientific and Cultural Organization-UNESCO World Heritage List. In particular, the cultural landscape concept attracted international attention. Cultural landscapes are at the interface between nature and culture, tangible and intangible heritage, biological and cultural diversity they represent a closely woven net of relationships, the essence of culture and people's identity. Cultural landscapes are a focus of protected areas in a larger ecosystem context, and they are a symbol of the growing recognition of the fundamental links between local communities and their heritage, humankind and its natural environment (Rössler, 2007). According to UNESCO, it is possible to provide an authentic living environment and high quality of life for future generations, with the protection of cultural landscapes (Bekdemir, 2010).

According to Antrop (2004); cultural landscape as a concept gaining increasing importance today is important in terms of understanding and evaluating the value of landscapes. Identification of areas bearing cultural landscape characteristics in rapidly changing cities, creation of inventory and monitoring of changes in these areas; in terms of decision making, policy making and landscape management processes is very important and necessary ensuring reliable delivery in the process (Erduran Nemutlu, Sağllk, Kelkit, Akbulak, \& Devecioğlu, 2014). As a result of conservation of cultural landscapes, landscape areas offer economic, ecological, social, recreational and educational opportunities. Conservation studies in these areas provide opportunities for the improvement of our quality of life, for the protection and perception of urban identity (EHLA, 2014). Characteristics of cultural landscape are; tracing of historical civilizations and socio-cultural values, reflecting the characteristics of the settlement area and the life of local cultures, offering various possibilities for active and passive recreational activities, enhancing the visual landscape quality and cultural values (Selman, 2006).

Historic landscape ensures understanding the traditional structure of landscapes and also significantly contributes to the development, protection and emphasizing the historic character of landscapes on a local, regional and national scale (Demir \& Demirel, 2017). The historical urban landscape approach aims at preserving the quality of people's environment by increasing the productivity and sustainability of the urban areas while accepting the dynamic characteristics of the urban areas and improving their social and functional diversity. The preservation of urban heritage rests on the basis of a balanced and sustainable relationship between the urban and natural environment and the needs of present and future generations and the heritage from the past (EHLA, 2014).

World Heritage cultural landscapes are sites which are protected under the UNESCO World Heritage Convention for the outstanding value of the interaction between people and their environment. The Convention not only embodies tangible and intangible values both for natural and cultural heritage, it also acknowledges in its implementation the recognition of traditional management system, customary law and long-established customary techniques and knowledge to protect the cultural and natural heritage. Through these protection systems, World Heritage sites contribute to sustainable local 
and regional development (Rössler, 2007).

There are 13 assets in Turkey in the UNESCO World Heritage list. Selimiye Mosque and its social komplex in Edirne is one of the important works on this list. Edirne Selimiye Mosque and its social komplex entered the world heritage list at the meeting held in Paris on June 27, 2011 by the world heritage committee because of being a masterpiece of human creativity, presenting a valuable example of the type of building representing one or more meaningful periods or of the architectural or technological landscape collection of history of humanity. In addition to Selimiye, Edirne city has a cultural structure; Uzunköprü (2015) and Sultan II. Beyazid Han Social Komplex (2016) was on the UNESCO World Heritage Tentative List and Kırkpınar Oil Wrestling Festival (2010) is also on the UNESCO Intangible Cultural Heritage List (UNESCO, 2012). The appreciation of the visual landscape quality is important for understanding the processes such as planning, design, management and understanding of the historical and cultural landscape values found in Edirne.

\subsection{Visual Landscape Quality}

Landscape components such as forests, water surfaces, bare fields, geomorphological structures and various cultural features (eg archeological value places/structures), reveal the visual landscape character of the area. Visual landscape is an interactive and dynamic structure integrated with human perception and liking in connection with human psychology of natural and cultural landscape elements (Kuter \& Aytaş, 2013). According to Daniel (2001), visual landscape quality is a common product of certain landscape features interacting with psychological (perceptual, cognitive/cognitive, emotional) processes depending on human observation (Benliay \& Soydan, 2015). Visual landscape; can be obtained not only by the physical features of the landscape, but also by putting individual thoughts by observers following it, which are also intertwined with the landscape, apart from the findings obtained from the measurable sources (Bergen, Ulbricht, Fridley, \& Ganter, 1995). According to Linehan and Gross (1998), landform, biological and ecological structure, spiritual values, historical, cultural and social structure are influential on landscape quality. According to Gobster (1999), landscape which has superior characteristics have more visual quality in terms of recreational value, durability, ecological characteristics and naturalness. According to Kaplan et al., (1999); Pullar and Tidey, (2001) and Yürekli (1977), visual (impact) evaluation studies are based on evaluating the visual qualities of a place or route, space fiction and social life in a perceptual, basically functional relationship. In urban settlements; it becomes functional by a wide area ranging from the whole of the city or settlement to its parts or a single route (such as a boulevard, a street, a street) (Kaplan \& Hepcan, 2004). Visual character or landscape quality is a major component of the natural and cultural environment and affects the overall quality of a tourist / recreational experience (Clay \& Daniel, 2000).

According to Kane (1981); the reasons for doing visual quality analysis; to help identify and list priority areas of in protection areas, and to provide a method of comparing research areas from the aesthetic point of view. Besides, visual quality analysis can be done as a method to determine the follow-up of adverse changes in the quality of landscapes in special areas through periodic evaluation methods and as a method to 
determine changes in landscape and effects of certain types of human activities. Visual quality analysis is important to better understand the differences in landscape preferences between various social groups (women/men, young/old, visitors/locals, etc.) and individuals with different educational backgrounds (Gültürk \& Şişman, 2015).

When the approaches on aesthetic perception are considered, it can be seen that different methods were used concerning the studies on 'visual quality assessment'. While the expert approach is particularly powerful in environmental management applications, the approaches which are based on user perception are dominant in research projects. (Erdönmez \& Kaptanoğlu, 2008).

In the perception-based assessment method, observers are asked to rate the landscape quality by scoring, or to choose from landscapes that are usually presented with photographs. (Daniel T. , 2001). In visual landscape assessments in accordance with landscape planning, design and management objectives- there are several inventory analysis and assessments for different visual characteristics of landscape (Palmer \& Hoffman, 2000). There are three main types of models used in evaluating visual landscape quality. These models are; physical, psychological and psychophysical approaches. When studies conducted in recent years are examined, it is clear that the most preferred approach model is the psychophysical model (a model in which user preferences are reviewed by expert observations). The psychophysical approach model tries to determine the mathematical relationship between the physical characteristics of the landscape (topography, vegetation, etc.) and perceptual judgments of the observers (Uzzell, 1991). The results of psychophysical studies are mostly the statistical measurements of public perception of landscape quality and the identification of environmental elements that resource managers can manipulate in relation to perceptual responses. The most commonly used technique for determining these relationships is multiple regression analysis (Buhyoff, Miller, Roach, Zhou, \& Fuller, 1994).

\section{The Material and Methods}

The material of the study is created images representing historical and cultural landscapes in and around the city center of Edirne. The area's hosting of many civilizations in the historical process has made it possible to have a large number of tangible and intangible cultural heritage items. Edirne, Turkey is the western border of the nearest settlement and as a major transit hub for the country (Figure 1). It is the gateway of the country to Europe. It was the capital of the Ottoman Empire for almost 90 years. It has come to the forefront with examples of magnificent religious buildings and civil architecture that brought the Ottoman architecture to its peak. In Edirne, religious buildings (such as mosque, mosque, tekke, tomb), education and socio-cultural structures (such as madrasa, complex), commercial buildings (such as inns and bazaars), minority buildings (like churches and synagogues), fountain, etc.), as well as many examples of civil architecture are among the items that give the identity of the city and reflect Ottoman culture and architecture (Misirlı \& Benian, 2014). Selimiye Mosque and Kulliyesi, one of the most important works of Mimar Sinan, constitutes one of the important cultural heritages of Edirne and the World with its urban location and architectural features. This cultural and architectural diversity coming from different 
periods of history has also made Edirne an important tourism city. For this reason, the importance of visual landscape quality in terms of tourism and recreation also increases considerably. Selimiye Mosque and Kulliyesi, as well as the cultural heritage of the Ottoman era such as the Old Mosque, Three Honorable Mosques, Macedonian Tower, Bedesten and Alipaşa Covered Bazaar, as well as concrete cultural heritage values such as Italian Catholic Church, Great Edirne Synagogue, Sveti Georgi Bulgarian Church; there are intangible cultural heritage values such as Kirkpınar oil wrestling festival, hidirellez, traditional handicrafts and traditional food.

A Visual quality assessment was applied in the research method and it was benefited from the studies that made the parameters (Tveit, Ode, \& Fry, 2006), (Bozhüyük, 2007), (Gültürk \& Şişman, 2015) ve (Tüfekçioğlu, 2008).

In this study, in order to determine the visual quality of landscapes with different structures, textures and characters, a questionnaire was applied to the expert groups of photographs representing the areas.

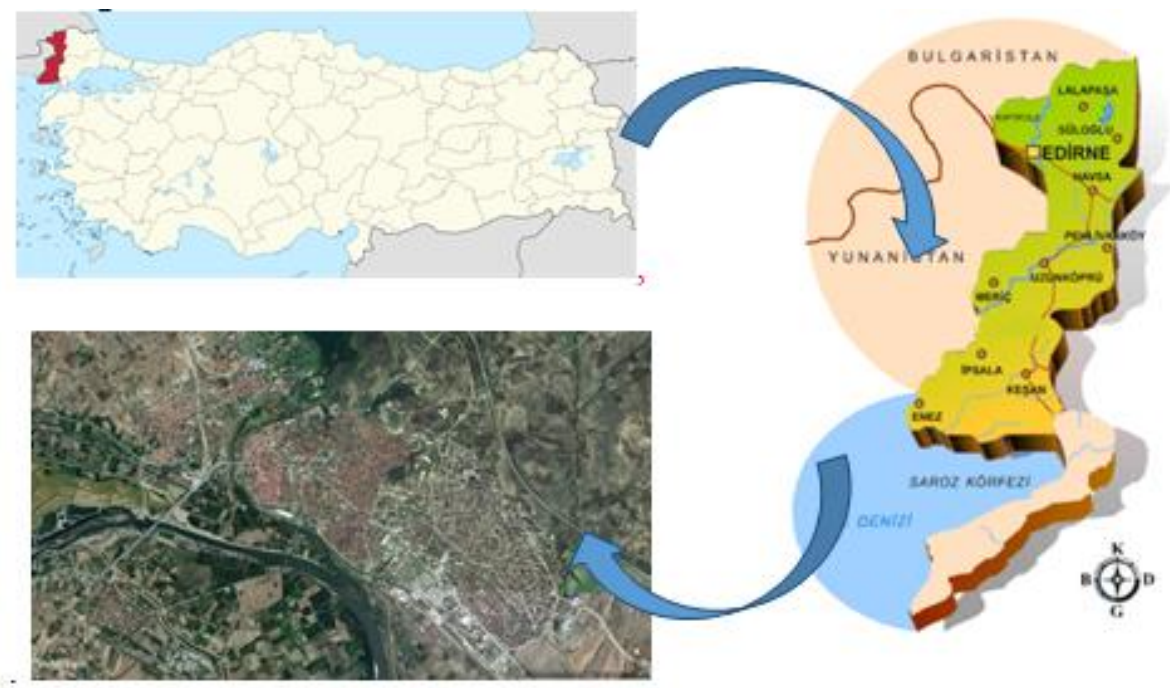

Figure.1 Edirne city location in Turkey

The expert group consists of 15 people composed of landscape architect, architect and city planner. Photographs were shown to the experts, reflecting the historical and cultural potential of the city of Edirne, as well as areas of tourism potential for the city. These photographs (Figure.2) (Figure.3) include religious buildings (1,2,3,15,16), social complex $(1,4)$, towers and monuments $(5,17,18)$, civil architecture items $(6,8,20,21,22)$, palace buildings $(9,10,11,12,13)$, bridge (7), river (19) and socio-cultural values $(23,24)$. According to the Likert scale, the photographs were scored between 1 and 5 (5 highest, 4 highest, 3 medium, 2 lowest and 1 lowest) in the direction of the determined parameters in Table 1. According to the parameters, Powerpoint presentations are shown by showing photos. Fields with high visual landscape value are questioned in terms of parameters. The obtained data were evaluated using the IBM SPSS Statistics 20 program. 
Table.1 Parameters and criteria (Tveit, Ode, \& Fry, 2006) and (Tüfekçioğlu, 2008) were developed.

\begin{tabular}{|c|c|}
\hline Parameters & Descriptions \\
\hline Coherence & $\begin{array}{l}\text { The elements that make up the landscape are the level of unity, integrity } \\
\text { and regularity. It is the level of perception of the different areas that } \\
\text { make up the place clearly and clearly. Harmony, unity, integrity etc. The } \\
\text { visual effects that visual elements create in such a way as to form the } \\
\text { whole bit are best suited for high scores.. }\end{array}$ \\
\hline Imageability & $\begin{array}{l}\text { It creates a strong visual image in the observer with its natural and } \\
\text { cultural characteristics and makes the landscape noticeable. It is the } \\
\text { holistic nature of the landscape. It is preferable to give a high score } \\
\text { when things like place spirit, uniqueness are involved. }\end{array}$ \\
\hline Hist & $\begin{array}{l}\text { It is preferable that the area is influenced by different historical periods } \\
\text { and that the diversity of the historical layers in that area increases the } \\
\text { quality of the landscape. }\end{array}$ \\
\hline Sen & $\begin{array}{l}\text { It is appropriate that the place has a high point by its originality, its } \\
\text { difference, the feeling of people having a sense of belonging to the area. } \\
\text { Difference, mystery, authenticity, place identity etc. }\end{array}$ \\
\hline ssiveness & $\begin{array}{l}\text { It is best if the scene has regular elements or net arrangements and a } \\
\text { score according to the beauty of the landscape. Visibility, clarity, clarity, } \\
\text { etc., }\end{array}$ \\
\hline Sten & $\begin{array}{l}\text { If it is thought that the elements that make up the visual are well- } \\
\text { maintained, it should be given a high score. }\end{array}$ \\
\hline Cor & $\begin{array}{l}\text { The diversity, richness and distribution of landscaping elements and } \\
\text { their characteristics are defined. Different forms of visual elements } \\
\text { coexist in the same environment. High scores should be given if these } \\
\text { differences are considered to be excessive. Diversity, diversity, } \\
\text { complexity of tissue and shapes, etc. }\end{array}$ \\
\hline Legi & $\begin{array}{l}\text { If it is thought that interpretation of the image is confusing or difficult, } \\
\text { it should be given low points. Perceptibility, portability, accessibility etc. }\end{array}$ \\
\hline Originality & $\begin{array}{l}\text { Architecture, texture, materials, etc high scores should be given if they } \\
\text { have a different structure from other studies. }\end{array}$ \\
\hline Accessibility & If the display or area is easy to reach, it should be rated high. \\
\hline Naturalness & $\begin{array}{l}\text { If there are more natural scenery features available in the visual, it is } \\
\text { better to give a high score. }\end{array}$ \\
\hline Security & $\begin{array}{l}\text { If the visual components are perceived as evoking danger or danger, a } \\
\text { high score should be given if they offer a low score, a welcoming, safe } \\
\text { and secure appearance. }\end{array}$ \\
\hline Inconsistency & $\begin{array}{l}\text { When viewed from the point of view, it is preferable to give a low score } \\
\text { when there is no compatibility with the subjects such as the diversity of } \\
\text { the elements, structure and environment, material and perception of } \\
\text { the field. }\end{array}$ \\
\hline City ident & Items that reflect the identity of the place should be given a high score. \\
\hline
\end{tabular}




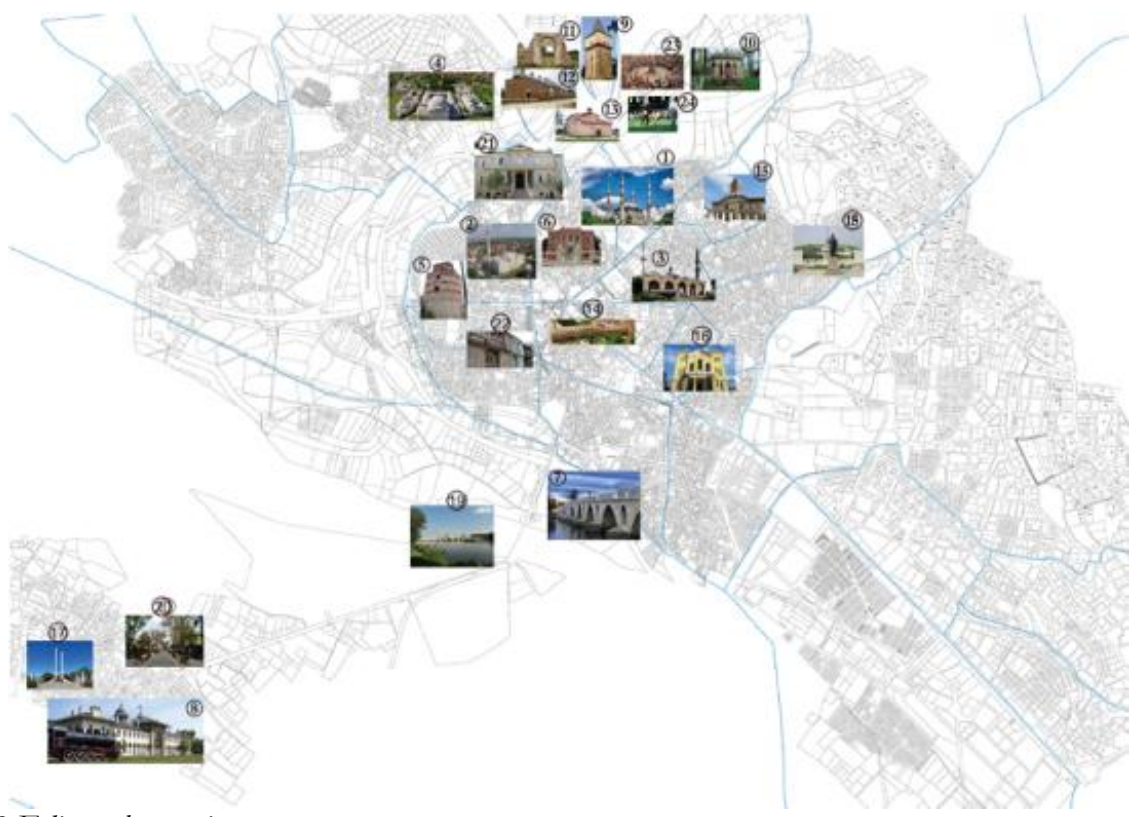

Figure.2 Edirne photo points

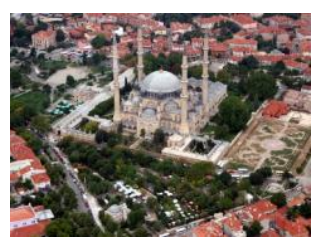

1-Selimiye Mosque and its Social Complex (URL1, 2018)

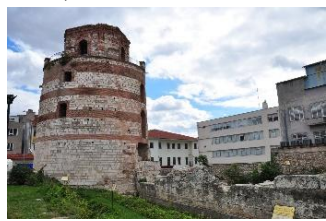

5-Macedonian Tower (URL5, 2018)

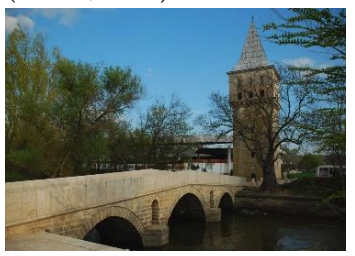

9-Justice Hall (URL9, 2018)

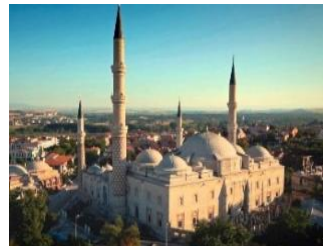

2-Üç Şerefeli Mosque

(URL2, 2018)

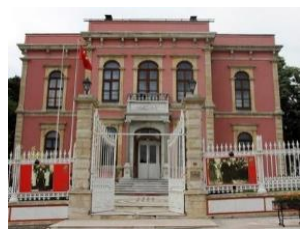

6-Edirne Municipality (URL6, 2018)

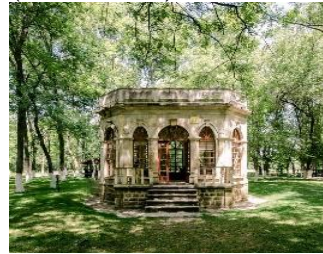

10-Hunting Lodg (URL10, 2018)

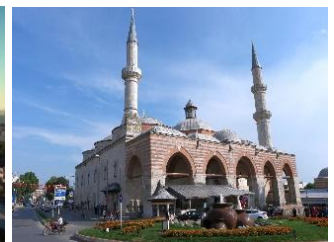

3-Old Mosque (URL3, 2018)

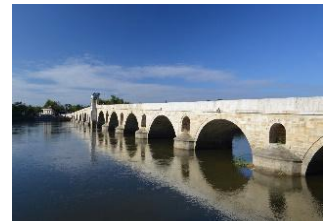

7-Meriç Bridge (URL7, 2018)

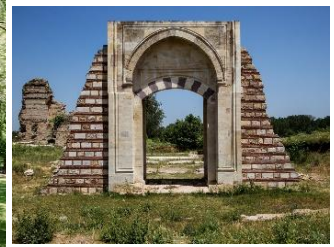

11-Saray-1 Cedid-i Amire (URL11, 2018)

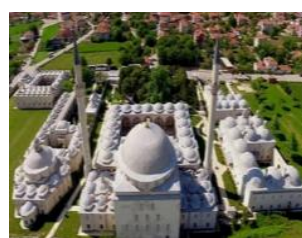

4-Sultan Bayezid II Mosque Complex (URL4, 2018)

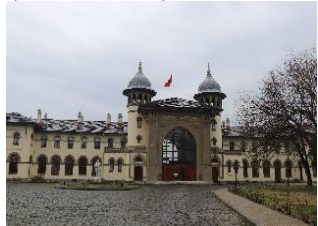

8-Faculty Of Fine Arts (URL8, 2018)

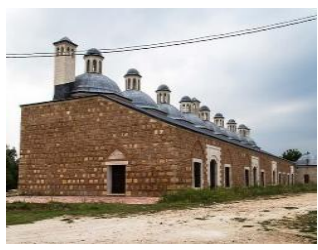

12-Imperial Kitchen (URL12, 2018) 


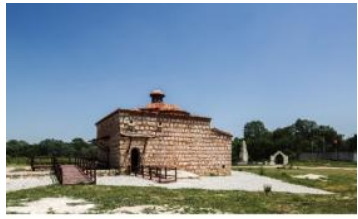

13-Sand Pavilion

Bathhouse (URL13, 2018)

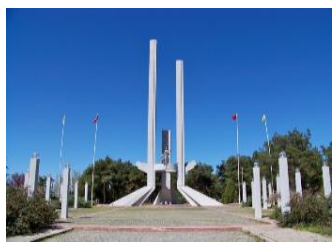

17-Lausanne monument (URL17, 2018)

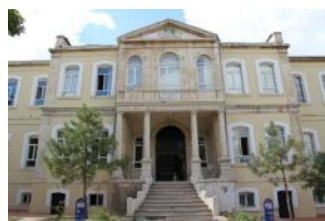

21-Faculty of Architecture (URL21, 2018)

Figure.3 Workspace evaluation photos

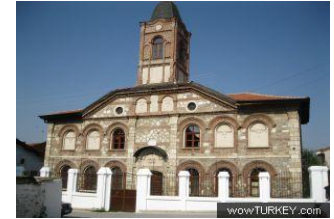

15-Church Sweti

Georgi (URL15, 2018)

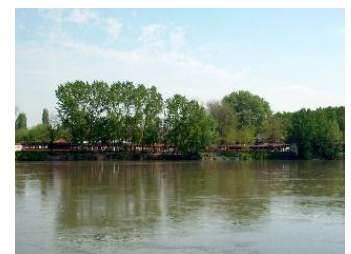

19-Meric river

(URL19, 2018)

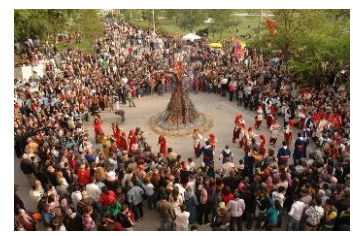

23-Hidirellez

(URL23, 2018)

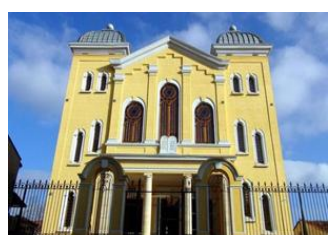

16-Grand Synagogue (URL16, 2018)

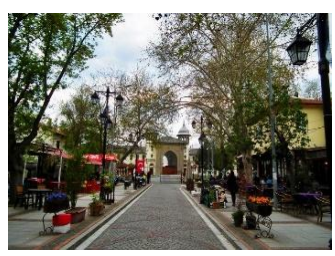

20-Karaağaç

(URL20, 2018)

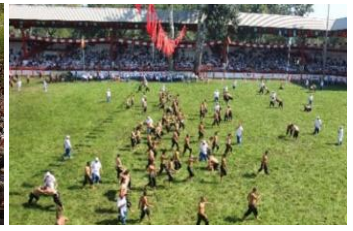

24-Kirkpınar oil wrestling festival (URL24, 2018)

\section{Findings}

As a result of the scores given in the visual landscape quality assessment for 24 different areas in the study, the average scores of the 14 parameters of 24 areas are given in Table 2. According to this evaluation, 7 of the 14 parameters (Sultan Bayezid II Mosque Complex) have the highest scores (Figure.4). The highest average score in field 4 is: coherence, historicity, visual impressiveness, sense of place, stewardship, legibilty and originality. Macedonia tower(5) of 11 of the 14 parameters received the lowest scores (Figure.5) Macedonia tower has The lowest average score in field 5 is: stewardship, naturalness, complexity, inconsistency, coherence, visual impressiveness, legibility.

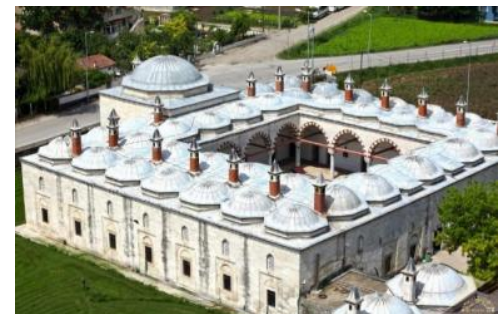

Figure.4. Sultan Bayezid II Mosque Complex (URL4, 2018)

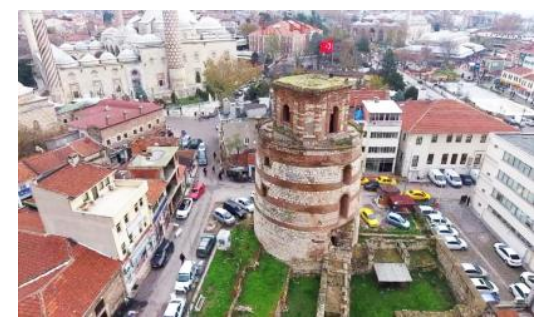

Figure5. Macedonia Tower (URL26, 2018 
"Coherence" parameter, 1st picture has the highest score by the experts with 5.00 points. Selimiye Mosque and Külliyesinin architectural texture and structure of the original and especially on the list of Unesco heritage because of the area has a very high value in terms of integrity. "Imageability" parameter, 1st picture has the highest score.

Table.2 Maximum and minimum field areas in visual quality parameters

\begin{tabular}{|l|c|c|}
\hline Parameters & Pictures & Average score \\
\hline Coherence & 1 & 5,00 \\
\hline Imageability & 1 & 4,83 \\
\hline Historicity & $1,2,24$ & 5,00 \\
\hline Sense of Place & 4 & 5,00 \\
\hline Visual impressiveness & $1,4,8$ & 4,83 \\
\hline Stewardship & 4 & 4,83 \\
\hline Complexity & 4 & 4,17 \\
\hline Legibility & 4 & 5,00 \\
\hline Originality & 1,4 & 5,00 \\
\hline Accessibility & $1,2,7$ & 4,67 \\
\hline Naturalness & 7 & 4,83 \\
\hline Security & 8,17 & 5,00 \\
\hline Inconsistency & $5,14,15$ & 1,83 \\
\hline City identity & $1,2,4,24$ & 4,83 \\
\hline
\end{tabular}

In terms of "historicity", regions 1, 2 and 24 have the highest score. In particular, the Kirkpinar Oil Wrestling Festival takes place among the intangible cultural heritage and has been organized every year in the city of Edirne. This value has also been assessed by the experts in terms of historical value. Selimiye Mosque and Old Mosque are the important works reflecting the time of the architectural textures. "Sense of place" was selected as the 4th region as the best reflecting region. In terms of "visual impressiveness", the highest score was 1.4 and 8. Especially the Faculty of Fine Arts has received high score due to its different architectural structure. The highest score in the "Stewardship", "complexity" and "legibility" parameters was obtained from the Sultan Bayezid II Mosque Complex. This is due to the fact that the entrance and exit of this area and its maintenance are controlled. At the same time, the area is open to tourists and tourists and carries an important value qualification as it maintains its historical identity and hosts faith tourism. From the point of view of the "originality" parameter, the highest score is the 1st and the 4th field. It has become 1, 2, and 7 of those who received the highest paun by experts in the "Accessibility" parameter. In the "Naturalness" parameter, area 7 is the most natural area. The Meric river and its environs are one of the important points of Edirne. It is a recreational area for the city. In terms of "security", the most secure areas have been areas 8 and 17. Entrants 8 and 17 are rated high because of the fact that they are operated between certain time zones and controlled. From the point of view of "inconsistency", the most complex area appears to be 5, 14 and 15 placements. When you look at the "city identity" parameter, the highest score is $1,2,4$ and 24 . 


\section{Results and Discussion}

Determination of scenery that identifies landscape, determination of potentials related to elements and components of landscape and constitution of basis within produced digital data have significant potential for usage of environmental sources in visual quality assessment (Kiper, Korkut, \& Topal, 2016). Visual quality assessment studies in accordance with planning, design and management improves both life quality and viewpoint for urban landscape contributing aesthetic improvement of cities (Aytaş \& Uzun, 2015). Providing sustainability through protecting viasul landscape variety and its components gain importance for protecting natural and cultural heritage and constitution of management policies (Anderson vd., 1979).

Historical environments particularly are the focal points of the city they take place in. However, they become passive among new structures within decreasing perception. Whereas they should be perceived as linkages between past and future. The historical identity of cities provides the continuity of historical environments with their period traces and make us to understand the past. The effects of historical environments carrying values on city identity are: providing legibility of cities; being original; symbolizing the city; making the society feel their history; presenting the harmonycontrast between old and new; creating a common language related with values and forms they carry; providing cultural sustainability; being nucleus point in foundation of cities according to (Karaday1, 2000).

An expert group of landscape architects, architects and urban designers evaluated the 24 visual descriptions belonging to historical and cultural values of Edirne city through 14 parameters within Likert scale between 1 and 5 in this study. The results are evaluated according to each parameter besides, the minimum and the maximum scores.

The historical pattern of Edirne city has been mainly consisted during and after Ottoman period. The historical and cultural values are predominantly located at the city center; gaining the city its identity and forming city silhouette. Religious and cultural buildings are especially tourism destinations. Thus spatial planning oriented tourism is required in Edirne as well as the other cities having cultural heritage besides, arrangement of cultural buildings with their surroundings, landscape planning, opportunities of design and management facilities are required in Edirne city. Although architectural value degree of our historical values are high, they got lower score regarding insufficient environmental arrangements according to our experts. Historical pattern loses its unity and originality during re-functioning and rehabilitation of especially Kaleiçi settlement, Karaağaç settlement and other religious and cultural buildings.

The identity and sense of space parameters are also evaluated as insufficient by experts as not reflecting what they have to be properly. Thus, it is mentioned vitally that the pattern must be protected. The II. Sultan Beyazid Complex with it new function as health museum serving today, got the highest score in terms of "sense of place, stewardship, complexity, legibility, originality and city identity" for reflecting our past properly and being supported by open-green spaces.

Outdoor fittings gain importance for increasing the visual quality and present silhouette of the city at urban historical spaces particularly Selimiye Mosque and Complex, Old Mosque and Üç Şerefeli Mosque. Similarly, outdoor lighting of historical buildings 
should be designed according to the integrity of them, besides contributing the enhance of structural fittings and perception of space and historical pattern.

Edirne is one of the wealthy cities in terms of city identity such as originality, complexity and being historical. Thus, spatial plan and conservation policies are required to be developed and controlled considering these cultural values. Besides, providing continuity with urban environment in terms of tourism, aesthetic, perception and visual attractiveness is vital.

Cities which gain wealth though aesthetic and cultural aspects, provides contribution in high life quality, inspired spaces, positive and pleasant environments, mental and physical health according to (Ode \& Fry, 2002). Thereby, historical and cultural spaces of Edirne effect life quality of the city as well as it, we claim. Besides, insufficient maintenance and protection of historical spaces are put forward. A better and concerned approach as well as supervision is suggested for sustainability. In this way, it is concluded that life quality and qualified livable spaces will be enhanced for the city, users and visitors.

\section{References}

Ak, K. (2013). Visual Quality Assessment Methods in Landscape Architecture Studies. (InTechOpen, Dü.) Advances in Landscape Architecture, Chapter11/279-290.

Amir, S., \& Gidalizon, E. (1990). Expert-based method for the evaluation of visual absorption capacity of the landscape. J.Environ. Manage.

Angileri, V., \& Toccolini, A. (1993). The assessment of visual quality as a tool for the conservation of rural landscape diversity. Landscape and Urban Planning, 24(1-4), 105-112.

Aytaş, İ., \& Uzun, S. (2015). Düzce Kent Merkezindeki Yaya Alanlarının Görsel Peyzaj Kalitesinin Belirlenmesi. Journal of the Faculty of Forestry Istanbul University, 11-29.

Bekdemir, L. (2010). Kültürel Peyzaj Değerlendirmesi: Dilek Yarımadası Büyük Menderes Deltası Milli park1 örneği. Ankara: Ankara Üniversitesi Fen Bilimleri Enstitüsü, Yüksek Lisans Tezi.

Bell, S. (1999). Landscape: Pattern, Perception and Process. London: E\& FN Spon.

Benliay, A., \& Soydan, O. (2015). Aspendos-Sillyon-Perge bisiklet güzergahı örneğinde peyzaj görsel kalitesi ve peyzaj özelliklerinin değerlendirilmesi. Artium, 3(1).

Bergen, S., Ulbricht, C., Fridley, J., \& Ganter, M. (1995). The validity of computer generated graphic images of forest landscapes. Journal of Environmental Psychology, 15, 135-146.

Bozhüyük, Z. (2007). Visual Impact Assessment of Some Historical Buildings and Environment in Erzurum City Centre. Erzurum: Atatürk University Graduate School of Natural and Applied Sciences Department of Landscape Architecture .

Buhyoff, G., Miller, P., Roach, J., Zhou, D., \& Fuller, L. (1994). An AI methodology for landscape visual assessments. AI Applications, 1-13.

Clay, G., \& Daniel, T. (2000). Scenic Landscape Assesssment: The Effects Of Land Management Jurisdiction On Public Perception Of Scenic Beauty. Landscape and Urban Planning(49), 1-13.

Coşkun, Ç., \& Kaplan, A. (2001). Urla (İzmir) Kent Merkezi ve Yakın Çevresi Örneğinde Görsel Etki Değerlendirmesi Çalışması. Ege Üniversitesi Araştırma Projesi-ZRF-36, İzmir.

Çakçı, I. (2007). Peyzaj Planlama Çalışmalarında Görsel Peyzaj Değerlendirmesine Yönelik Bir Yöntem Araştırması. Ankara: Ankara Üniversitesi Fen Bilimleri Enstitüsü, Doktora Tezi.

Daniel, T. (2001). Whither scenic beauty? Visual landscape quality assessment in the 21 st century. Landscape and Urban Planning, 54, 267-281.

Daniel, T., \& Vining, J. (1983). Methodological issues in the assessment of landscape quality. I. Altman, \& J. Wohlwill. içinde New York: Human Behavior and Environment: Advances in Theory and Research (Vol. 6, pp. 39- 84) Plenum Press.

Demir, S., \& Demirel, Ö. (2017). Historical Landscape Classification and Assessment. Journal of the International Scientific Researches, 186-195. 
EHLA. (2014). Tarihi Peyzaj ve Kültürel Mirasın Değerlerlendirilmesi Çalıştayı Özet Raporu. Edirne: İstanbul Teknik Üniversitesi.

Erdönmez, M. Ö., \& Kaptanoğlu, A. (2008). Landscape Aesthetic and Visual Quality Assessment. İstanbul Üniversitesi Orman Fakültesi Yayınları, 58(1), 39-51.

Erduran Nemutlu, F., Sağlık, A., Kelkit, A., Akbulak, C., \& Devecioğlu, N. (2014). Çanakkale kenti kültürel peyzaj değerlerinin belirlenmesi. Uluslararası Hakemli Tasarım ve Mimarlık Dergisi, 25-40.

Gültürk, P., \& Şişman, E. (2015). Tekirdağ Kent Merkezi Kıyı Şeridinin Görsel Peyzaj Kalitesi Yönünden Değerlendirilmesi ve Mekan Tercihine Etkisi. Journal of Adnan Menderes University Agricultural Faculty, 12(1), 81-89.

Hepcan, C. (2003). The Study in the context of visual impact assessment of Urla (İzmir) town center and its environs. İzmir: Ege University, Institute of Science and Landscape Architecture Department, M.Sc.

Kane, P. (1981). Assessing Landscape Attractiveness: A Comparative Test of Two New Method. Applied Geogr.

Kaplan, A., \& Hepcan, Ç. (2004). Ege Üniversitesi Kampüsü ‘Sevgi Yolu'nun Görsel (Etki) Değerlendirme Çalışması. Ege Üniversitesi Ziraat Fakültesi Dergisi, 41(1), 159-167. doi:1018-8851

Kaptanoğlu, A. (2006). Peyzaj Değerlendirmesinde Görsel Canlandırma Tekniklerinin Kullanıcı Tercihine Etkileri. İstanbul: İstanbul Üni versitesi Orman Fakültesi,Fen Bilimleri Enstitüsü, Peyzaj Mimarlığ1 Anabilim Dalı Doktora Tezi.

Karadayı, G. (2000). Kent Kimliğinin Sürdürülebilirliği ve Görsel Etki Değerlendirmesi: Trabzon Örneği. Trabzon: Karadeniz Teknik Üniversitesi, Fen Bilimleri Enstitüsü.

Kiper, T., (2013). Kentsel ve Kırsal Alanların Planlamasında Kimliğin Rolü. Türk Bilimsel Derlemeler Dergisi, 6(2), 73-77.

Kiper, T., Korkut, A., \& Topal, T. (2016). Kıyıköy Örneğinde Ekoturizm Planlamasına Yönelik Görsel Peyzaj Analizinin Uygulanması. Tekirdağ: N.K.Ü. Güzel Sanatlar, Tasarım ve Mimarlık Fakültesi.

Krause, C. (2001). Our visual landscape: Managing the landscape under special consideration of visual aspects. Landscape and Urban Planning, 54(1-4), 239-254.

Kuter, N., \& Aytaş, İ. (2013). Görsel Peyzaj Kalitesinin Değerlendirilmesinde Kullanılan Yöntemler. Peyzaj Mimarlığ1 5. Kongresi, (s. 737-753). Adana.

L.C.A. (2008). Landscape Character Assessment. http://www.landscapecharacter.org.uk/ adresinden alındı

Misırlı, A., \& Benian, E. (2014). Evaluation of The Historical City Edirne Through Cultural Assets. Humanities and Social Sciences Review (HSSR), 3(2), 309-325.

Ode, A., \& Fry, G. (2002). Visual Aspect in Urban Woodland Management. Urban Forestry \& Urban Greening, 46.

Palmer, J., \& Hoffman, R. (2000). Rating Reliability and Representation Validity in Scenic Landscape Assessment. Landscape and Urban Planning, 54(2001), 149-161.

Porteus, J. (1996). Environmental Aesthetics: Ideas, Politics and Planning. London: Routledge,London.\&FN Spon.

Rössler, M. (2007). World Heritage Cultural Landscape; A UNESCO Flagship Programme 1992-2006. Landscape Research, 31(4), 333-353.

Selman, P. (2006). Planning at the landscape scale. New York: The RTPI Library Series, Routledge Taylor\& Francis Group .

Tüfekçioğlu, H. (2008). Tarihsel Çevrede Görsel Peyzaj Kalite Değerlendirmesi İstanbul Yedikule Örneği. İstanbul: İstanbul Teknik Üniversitesi, Fen Bilimleri Enstitüsü.

Tveit, M., Ode, A., \& Fry, G. (2006). Key Concepts in a Framework for Analysing Visual Landscape Character. Landscape Research, 31(3), 229-255.

UNESCO. (2012). Cultural Landscape. https://whc.unesco.org/en/culturallandscape/

URL1. (2018). http://www.kilsanblog.com/unesco-dunya-mirasi-mimari/edirne-selimiye-camisi-kulliyesi/.

URL10. (2018). http://www.edirnekulturturizm.gov.tr/TR,85347/sarayici-alani.html.

URL11. (2018). https://www.rotasenin.com/edirne-sarayi.

URL12. (2018). http://www.arkitera.com/soylesi/831/osmanli-arkeolojisinin-daha-saglam-temelleruzerinde-gelismesine-onculluk-etmek-istiyoruz/3.

URL13. (2018). http://www.edirnekulturturizm.gov.tr/TR,85347/sarayici-alani.html.

URL14. (2018). http://www.edirnekulturturizm.gov.tr/TR,76567/rustempasa-kervansarayi.html.

URL15. (2018). http://wowturkey.com/forum/viewtopic.php?t=138730. 
URL16. (2018). http://www.kocaelihaberajansi.com/edirne-buyuk-sinagogu-artik-gelecek-nesillereemanet.html.

URL17. (2018). http://turkiyedogarehberi.blogspot.com/2015/12/edirnedeki-antlar.html.

URL18. (2018). http://turkiyedogarehberi.blogspot.com/2015/12/edirnedeki-antlar.html.

URL19. (2018). https://www.flickr.com/photos/incubo78/2567654323/.

URL2. (2018). http://blog.biletbayi.com/edirnede-gezilecek-yerler.html/maxresdefault-9.

URL20. (2018). http://www.trakyagezi.com/karaagaci-yurumek/.

URL21. (2018). https://www.kulturportali.gov.tr/turkiye/edirne/kulturenvanteri/harbiye-kislasi-.

URL22. (2018). http://www.havaneli.com/edirneden-selamlar.html.

URL23. (2018). http://ettder.org/tunca-nehri-kiyisinda-hidirellez-kakava-senligi-edirne-5-6-mayis/.

URL24. (2018). https://www.azbibak.com/kirkpinar-yagli-guresleri-hakkinda-bilgi/.

URL26. (2018). https://www.tourmag.com.tr/edirnedeki-makedonya-saat-kulesi-restore-edilecek/.

URL3. (2018). http://turkisharchaeonews.net/object/old-mosque-edirne.

URL4. (2018). https://gezilmesigerekenyerler.com/gezilecek-yerler/sultan-ii-bayezid-kulliyesi-saglik-muzesitum-gerekli-bilgiler-edirne.html.

URL5. (2018). http://turkisharchaeonews.net/object/fortifications-and-macedonian-tower-edirne.

URL6. (2018). http://www.haberturk.com/polemik/haber/985287-edirne-belediyesinde-hayalet-avi.

URL7. (2018). https://www.flickr.com/photos/ersinkaplan/7527370074. adresinden alınd1

URL8. (2018).http://kolajart.com/wp/2016/07/03/trakya-universitesi-guzel-sanatlar-fakultesi-2016-2017ozel-yetenek-sinavlari-ilani/

URL9. (2018). http://www.edirnekulturturizm.gov.tr/TR,85347/sarayici-alani.html\#.

Uzzell, D. (1991). Environmental psychological perspectives on landscape. Landscape Research, 3-10. 